\title{
Preliminary data on the geographical distribution of Drosophila species within morphoclimatic domains of Brazil. III. The cardini group
}

\author{
Carlos Ribeiro Vilela ${ }^{1}$ \\ Antônio Fernando Gouvêa da Silva ${ }^{1,3}$ \\ Fábio de Melo Sene ${ }^{2}$
}

\begin{abstract}
A reanalysis, based on museum specimens, of our previously published data on the geographical distribution of the species of Drosophila belonging to the cardini group in Brazil is presented and discussed. As previously recorded in several papers, including ours, the following four species were recognized: D. cardini, D. cardinoides, D. neocardini, and $D$. polymorpha. However, it was realized that most of the flies we have previously identified as Drosophila cardinoides belong in fact to Drosophila cardini. To facilitate the proper identification of these four near-sibling species, their holotypes were analyzed and their terminalia were described and illustrated. A key to the four species is also provided.
\end{abstract}

KeYworDs. Diptera; Drosophilidae; holotypes; male terminalia; Neotropical Region.

\section{INTRODUCTION}

The Drosophila cardini species group belonging to the subgenus Drosophila was established by STURTEVANT (1942). It currently includes 16 species of a large geographical distribution in the Americas (Sturtevant 1942; WheEler 1949; HeEd 1962; HeED \& Russell 1971). They are medium-sized flies (2 $3.5 \mathrm{~mm}$ in length) and morphologically extremely similar, but promptly recognized as belonging to their group by their reddish-brown or yellowish, conspicuously shining thorax, and by the presence of several patterns (polymorphic in at least two species) of distal black bands in the tergites, strikingly contrasting with the proximal mostly yellowish areas. The group comprises two subgroups: dunni including species from the Antilles and cardini with species occurring mainly in the continent in addition to $D$. bedicheki described from Trinidad and D. acutilabella found both in the mainland and in some Caribbean islands (HeEd \& Krishnamurthy 1959; HeEd 1962; HeEd \& Russell 1971). According to HeED (1957), PIPKIN (1965) and PIPKIN et al. (1966), the ecological versatility of these species could be the cause of the wide distribution of the group. The cardini species group is phylogenetically related to the Droso- phila calloptera, the Drosophila guarani and the Drosophila tripunctata species groups (FROTA-PESSOA 1954; THROCKMORTON 1962; GRIMALDI 1990), and the limits among them are not always clear-cut.

Before late '60s (DobZhansky \& Pavan 1943, 1950; Streisinger 1946; Frota-Pessoa 1952; Patterson \& Stone 1952; CunHa 1955; Pavan 1959; Futch 1962), only 3 species of the group had been recorded in Brazil: D. cardinoides Dobzhansky \& Pavan, 1943, D. neocardini Streisinger, 1946 and D. polymorpha Dobzhansky \& Pavan, 1943. Later on, the occurrence of D.cardini Sturtevant, 1916 in Brazil was registered in several papers (Mourão et al. 1965; HeED \& RusSELl 1971; NapP \& CoRdeiro 1978; Sene et al. 1980; Val et al. 1981; Valente \& AraúJo 1991; Tidon-Sklorz et al. 1994; VIlela \& Mori 1999).

More than twenty years ago, SENE et al. (1980) reported a preliminary data on the geographical distribution of Drosophila species in Brazil. Among the 110,914 collected flies, a total of 6,608 specimens were ascribed to four species of Drosophila belonging to the cardini group. However, reanalyzing the preserved specimens, we have found some mistakes in the identification of imagoes belonging to two of the species in the cardini group, namely $D$. cardini and $D$. cardinoides.

\footnotetext{
1. Departamento de Biologia, Instituto de Biociências, Universidade de São Paulo. Caixa Postal 11461, 05422-970 São Paulo-SP, Brazil. E-mail: crvilela@ib.usp.br

2. Departamento de Genética, Faculdade de Medicina de Ribeirão Preto, Universidade de São Paulo. 14049-900 Ribeirão Preto-SP, Brazil. E-mail: famesene@usp.br

3. Fellow from FAPESP.
} 
The purpose of the present work, which is the third of a series (SENE et al. 1980; Vilela et al. 1983), is to clarify those identifications using the external morphology, including especially the setae and the shape of male palpi, as well as the male terminalia which were also redescribed and illustrated, based on the holotypes of the four sampled species.

\section{MATERIAL AND METHODS}

The details of the methods and materials were described in

Table I. Numbers of specimens of four species of Drosophila belonging to the cardini group sampled in fruit-baited traps in several types of Brazilian environments from April 1976 to June 1978. Refer to the first paper of this series (SENE et al. 1980) for an annotated list of the sampled localities.

\begin{tabular}{|c|c|c|c|c|c|c|}
\hline \multirow[t]{2}{*}{ Environment } & \multirow{2}{*}{$\begin{array}{l}\text { Locality, State (code according to } \\
\text { SENE et al. } 1980 \text { ) }\end{array}$} & \multicolumn{5}{|c|}{ Species } \\
\hline & & D.cardini & D.cardinoides & D.neocardini & D.polymorpha & Total \\
\hline \multirow{7}{*}{ Forests } & Boracéia, SP (1) & 0 & 0 & 0 & 382 & 382 \\
\hline & Serra da Bocaina, SP (2) & 0 & 0 & 0 & 78 & 78 \\
\hline & Teresópolis, RJ (5) & 0 & 10 & 0 & 68 & 78 \\
\hline & Santa Tereza, ES (6) & 0 & 1 & 0 & 13 & 14 \\
\hline & Peruíbe, SP (7) & 0 & 4 & 0 & 20 & 24 \\
\hline & Rio Ivaí, PR (8) & 14 & 2 & 411 & 2,943 & 3,370 \\
\hline & Piritiba, BA (9) & 55 & 2 & 27 & 49 & 133 \\
\hline \multirow[t]{2}{*}{ Restingas } & Peruíbe, SP (10) & 19 & 0 & 0 & 28 & 47 \\
\hline & Guaratuba, SP (11) & 10 & 0 & 0 & 26 & 36 \\
\hline Pantanal & Miranda, MS (12) & 49 & 12 & 5 & 142 & 208 \\
\hline \multirow{4}{*}{ Disturbed } & Irecê, BA (42) & 16 & 0 & 0 & 0 & 16 \\
\hline & Cabreúva, SP (44) & 12 & 0 & 0 & 3 & 15 \\
\hline & Rio Ligeiro, PR (45) & 34 & 40 & 40 & 89 & 203 \\
\hline & Correias, RJ (43) & 0 & 22 & 0 & 5 & 27 \\
\hline \multirow{2}{*}{$\begin{array}{l}\text { Rio Grande } \\
\text { do Sul }\end{array}$} & Guaritas, RS (21) & 6 & 0 & 0 & 9 & 15 \\
\hline & Jaguari, RS (22) & 7 & 0 & 0 & 9 & 16 \\
\hline \multirow{8}{*}{ Coast } & Barra do Maxaranguape, RN (13) & 2 & 0 & 0 & 0 & 2 \\
\hline & Arraial do Cabo, RJ (14) & 1 & 0 & 0 & 0 & 1 \\
\hline & Cabo Frio, RJ (15) & 1 & 0 & 0 & 0 & 1 \\
\hline & Guaratuba, SP (16) & 2 & 1 & 3 & 14 & 20 \\
\hline & Peruíbe, SP (17) & 91 & 10 & 0 & 23 & 124 \\
\hline & Barra Velha, SC (18) & 5 & 2 & 0 & 9 & 16 \\
\hline & Ilha de Santa Catarina, SC (19) & 0 & 0 & 1 & 0 & 1 \\
\hline & Tramandaí, RS (20) & 51 & 2 & 2 & 297 & 352 \\
\hline Chaco & Bela Vista, MS (41) & 143 & 35 & 0 & 121 & 299 \\
\hline \multirow{8}{*}{ Cerrados } & Barreiras, BA (23) & 66 & 0 & 0 & 2 & 68 \\
\hline & Brasília, DF (24) & 5 & 4 & 0 & 3 & 12 \\
\hline & Lagoa Santa, MG (25) & 3 & 0 & 0 & 18 & 21 \\
\hline & Mogi Guaçu, SP (26) & 254 & 5 & 0 & 226 & 485 \\
\hline & São Carlos, SP (27) & 69 & 0 & 0 & 71 & 140 \\
\hline & Itu, SP (28) & 2 & 0 & 0 & 63 & 65 \\
\hline & Campo Grande, MS (29) & 17 & 25 & 0 & 33 & 75 \\
\hline & Caracol, MS (30) & 8 & 4 & 0 & 83 & 95 \\
\hline \multirow{10}{*}{ Caatingas } & Bom Jesus, RN (31) & 1 & 0 & 0 & 0 & 1 \\
\hline & Junco do Seridó, PB (32) & 26 & 0 & 0 & 0 & 26 \\
\hline & São José de Espinharas (41) & 41 & 0 & 0 & 0 & 41 \\
\hline & Milagres, BA (34) & 7 & 0 & 0 & 1 & 8 \\
\hline & Cachoeira dos Monteiros, BA (35) & 11 & 0 & 0 & 2 & 13 \\
\hline & Mira-Serra, BA (36) & 5 & 0 & 0 & 2 & 7 \\
\hline & Ibotirama, BA (37) & 24 & 0 & 0 & 4 & 28 \\
\hline & Barreiras, BA (38) & 10 & 0 & 0 & 0 & 10 \\
\hline & Cafarnaum, BA (39) & 20 & 0 & 0 & 2 & 22 \\
\hline & Xique-Xique, BA (40) & 13 & 0 & 0 & 0 & 13 \\
\hline Total & & 1,100 & 181 & 489 & 4,838 & 6,608 \\
\hline
\end{tabular}


SENE et al. (1980), who deposited the sampled specimens in the Museu de Zoologia, Universidade de São Paulo (MZSP), São Paulo (SP).

It should be stressed that the data included in the present paper have two main restrictions, as stated in the first one of this series of papers: 1 . most of the localities were sampled just once using artificial fruit-baited traps, thus at present we have no information on population fluctuations due to seasonal variations; 2 . the results could be influenced by differential preference of the flies attracted to artificial baits.

The postabdomens of the holotypes of $D$. cardini, $D$. cardinoides, D. neocardini and D. polymorpha, and of several non type specimens were removed, dissected by routine methods (WHEELER \& KAMBYSELLIS 1966), and are preserved in microvials, filled with glycerin, attached by the stopper to the pin of the respective specimen. Drawings of the terminalia of the holotypes were made using a microscope with an objective 40x and a camera lucida (1x).

The holotypes of Drosophila cardini and Drosophila neocardini are deposited in the American Museum of Natural History (AMNH), New York, USA, and those of $D$. cardinoides and D.polymorpha are housed in the MZSP, São Paulo, Brazil.

\section{RESULTS ANDDISCUSSION}

The results of the reanalysis of the specimens belonging to the cardini group included in the first paper of this series (SENE et al. 1980) are presented in Table I. It is now clear that most specimens we have previously identified as $D$. cardinoides are in fact $D$. cardini, especially those from the driest areas. They are so similar morphologically that they have probably been misidentified in the last decades. Freire-Maia \& Pavan (1949) stated that $D$. cardinoides could be a synonym of $D$. cardini, although the latter species, based on its original description, has metaphase plates clearly different (for further notes refer to WHEELER 1949) from those of D. cardinoides. We afford the opinion that the absence of D. cardini in Brazil in earlier reports (e.g. Dobzhansky \& Pavan 1950; PAvan 1959) should be regarded with caution, although we are unable to investigate this suspicion since most of the specimens collected by earlier collectors were not preserved in museum collections. Moreover, as it happened with D. cardini in the Hawaiian islands (HERFORTH et al. 1984), there is also a possibility that this species could have been accidentally introduced later in the country after those earlier collections were made.

The majors changes involving the geographical distribution of $D$. cardinoides and $D$. cardini are as follows: $D$. cardinoides is absent in the caatingas (semi-arid areas), rare in the other dried environments, and occurs in low frequency in the wet Atlantic Forest, whereas D. cardini, the more abundant member of the group in the caatingas, is as abundant as D. polymorpha in the cerrados (type of savannas), the coast and the restingas (strand vegetation), and is absent in the Atlantic Forest, although occurs in inland Forests. Based on its abundance it seems that the latter species is better adapted to drier environments than the former.
The geographical distribution of D. polymorpha and $D$. neocardini in Brazil remains the same as presented in SENE $e t$ al. (1980) because no mistake has been detected for them. However, the data are being republished in Table I for comparison purposes. Two of the subspecies of $D$. neocardini, namely $D$. $n$. itambacuriensis and D. n. mourensis were described by Cunha (1955) based on the abdomen color pattern and on reproductive isolation. Whether or not just one or both forms are present among the sampled flies is unknown as we were unable to tell them apart based on terminalia analysis only.

Although the terminalia of the four species of Drosophila belonging to the cardini group known to occur in Brazil have already been described and figured by different authors (StalKer 1953; HeEd 1962; HeEd \& Russell 1971; Val 1982; SuYo et al. 1981), they were incompletely illustrated. To facilitate the proper identification of the species we redescribed and illustrated their terminalia below, based on the holotypes.

\section{Drosophila cardini Sturtevant, 1916}

(Figs. 1-8)

Drosophila cardini Sturtevant, 1916:336.

Drosophila (Drosophila) cardini; Sturtevant, 1942:32; Hsu, 1949:138 (epandrium; see comments by STALKER, 1953: 350); Malogolowkin, 1953:256 (male terminalia); Stalker, 1953:345 (key), 349 (epandrium); Heed, 1962:176 (tip of aedeagus, referred to as apodeme); Suyo et al. 1981 (male terminalia).

Specimen dissected. Male holotype, labelled "Havana, Cuba, Jan. Feb. 1915 / Type / Am. Mus. Nat. Hist. Dept. Invert. Zool., No. 24147 / Drosophila cardini Sturtevant", deposited in AMNH (New York).

Male terminalia. Epandrium with about 3 setae just above surstylus, without upper setae, slightly microtrichose at dorsal area; ventral lobe absent. Cerci not fused to epandrium; tip of cercus bearing 3 remarkably long, tightly joined setae. Surstylus dorsally sclerotized, ventrally membranous, not microtrichose, with about 7 short, cone-shaped prensisetae, 11 longer, coneshaped, sharply pointed outer setae and 13 thin inner setae that come up to outer surface; anterior margin mostly fused to posterior margin of epandrium by membranous tissue. Decasternum as in Figs. 1-2. Hypandrium as long as epandrium; bow present, sclerotized; gonopod fused to paraphysis, bearing one long seta; posterior margin of gonopod (just behind the seta) projected posteriorly, then becoming membranous; paraphysis apparently bare. Aedeagus straight, laterally flattened, bearing two conspicuous finger-shaped, dorsocaudal projections, subapically expanded in dorsal and ventral views, with a membranous sheath, covered with tiny spines; ventrodistal end rounded, laterally flattened, marginally serrated distally and covered with tiny spines; dorsal cleft at very proximal end; aedeagal apodeme as long as aedeagus, rodshaped; ventral rod widely fused to aedeagal apodeme as in Figs. 4-8. 

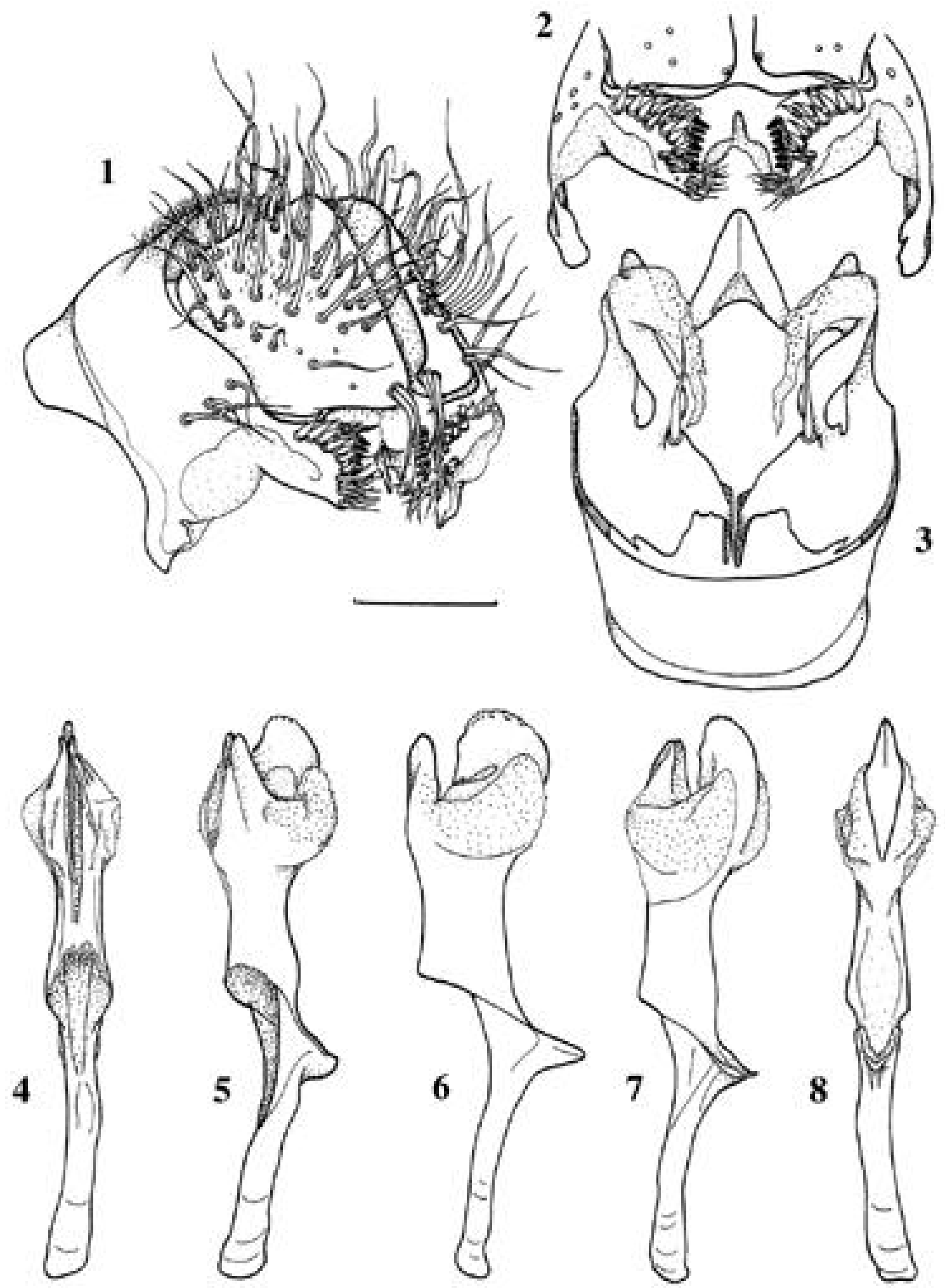

Figs. 1-8. Drosophila cardini Sturtevant, 1916, male terminalia, holotype. 1, epandrium, cerci, surstyli, and decasternum, oblique posterior view; 2, surstyli and decasternum, posterior view; 3, hypandrium and gonopods + paraphyses, posterior view; 4-8, aedeagus and aedeagal apodeme, several views from dorsal through ventral. All figures were drawn to the same scale. Bar $=0.1 \mathrm{~mm}$. 

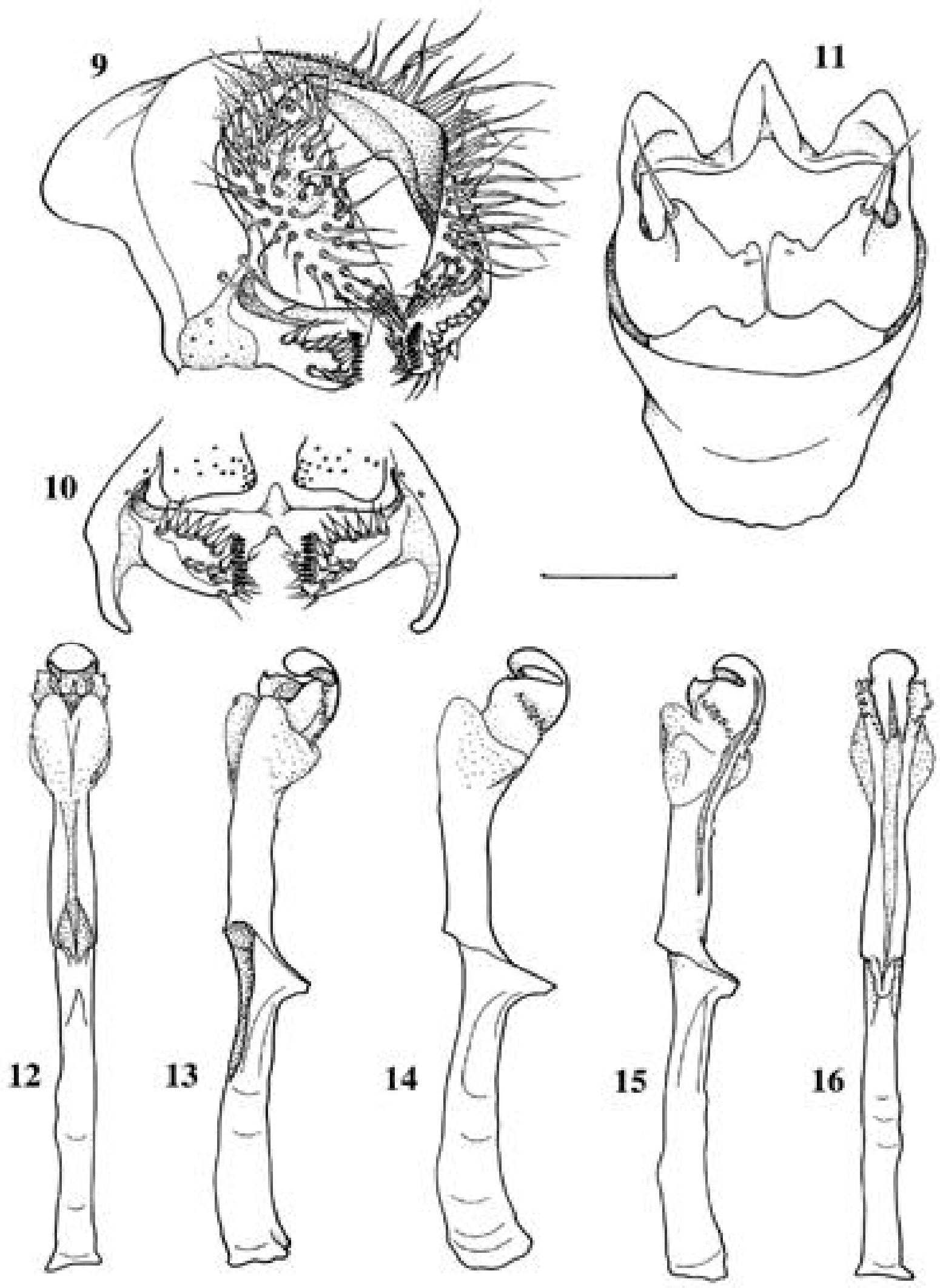

Figs. 9-16. Drosophila cardinoides Dobzhansky \& Pavan, 1943, male terminalia, holotype. 9, epandrium, cerci, surstyli, and decasternum, oblique posterior view; 10, surstyli and decasternum, posterior view; 11, hypandrium and gonopods + paraphyses, posterior view; 12-16, aedeagus and aedeagal apodeme, several views from dorsal through ventral. All figures were drawn to the same scale. Bar $=0.1 \mathrm{~mm}$. 
Drosophila cardinoides Dobzhansky \& Pavan, 1943

(Figs. 9-16)

Drosophila (Drosophila) cardinoides Dobzhansky \& Pavan, 1943:21; Streisinger, 1946:110 (male terminalia); Hsu, 1949:138 (epandrium); Stalker, 1953:344 (key), 349 (epandrium); Cova-Garcia \& Suárez, 1962:324 (egg, puparium, male and female terminalia); Heed, 1962:176 (tip of aedeagus, referred to as apodeme); Heed \& Russell, 1971:127 (tip of aedeagus, palpus); Val, 1982:324 (male teminalia, paratype).

Specimen dissected. Male holotype, labelled "Iporanga, São Paulo, VII-1942 / Drosophila cardinoides type/ HOLOTIPO”, deposited in MZSP (São Paulo).

Male terminalia. Epandrium with 2 setae just above surstylus, without upper setae, slightly microtrichose at dorsal area; ventral lobe absent. Cerci not fused to epandrium; tip of cercus bearing a tuft of thin setae. Surstylus dorsally strongly sclerotized, not microtrichose, with 8 short, cone-shaped prensisetae, about 12 longer, cone-shaped, sharply pointed outer setae, of which eight are organized in a curved row, and about 12 thin inner setae that come up to outer surface; anterior margin mostly fused to posterior margin of epandrium by membranous tissue. Decasternum as in Fig. 10. Hypandrium slightly longer than epandrium; bow present, sclerotized; gonopod fused to paraphysis, bearing one long seta; paraphysis bearing one setula. Aedeagus straight, rod-shaped, submedially expanded sligthly in dorsal and ventral views, with a membranous, dorsally splitted sheath, covered with tiny spines, which is followed by a serrated collar; subapically deeply incised dorsally and slightly projected ventrally; dorsal cleft at very proximal end; aedeagal apodeme as long as aedeagus, rod-shaped, slightly flattened laterally; ventral rod widely fused to aedeagal apodeme as in Figs. 13-15.

\section{Drosophila neocardini Streisinger, 1946}

(Figs. 17-24)

Drosophila (Drosophila) neocardini Streisinger, 1946:110 (male terminalia); Hsu, 1949:138 (epandrium); Stalker, 1953:344 (key), 347 (proboscis and palpus) 349 (male and female palpi); Heed, 1962:176 (tip of aedeagus, referred to as apodeme); Val, 1982:323 (male terminalia of paralectotype of subspecies itambacuriensis), 325 (male terminalia of paralectotype of subspecies mourensis).

Specimen dissected. Male holotype, labelled "TYPE / TEFFÉ, AMAZONAS, Th. DOBZHANSKY COLL. I DROSOPHILA NEOCARDINI SP. N., G. STREISINGER", deposited in AMNH (New York).

Male terminalia. Epandrium with one setae just above surstylus, without upper setae, slightly microtrichose at dorsal area; ventral lobe absent. Cerci not fused to epandrium; tip of cercus bearing 3 tightly joined setae, shorter than in $D$. polymorpha. Surstylus strongly sclerotized in dorsal region, not microtrichose, with about 6 short, cone-shaped prensisetae, ca. 7 longer, cone-shaped, sharply pointed outer setae and ca. 7 thin inner setae that come up to outer surface; anterior margin mostly fused to posterior margin of epandrium by membranous tissue. Decasternum as in Figs. 17, 18. Hypandrium as long as epandrium; bow present, sclerotized; gonopod fused to paraphysis, bearing one long seta; posterior margin of gonopod (just behind the seta) membranous and projected posteriorly; paraphysis apparently bare. Aedeagus straight, laterally flattened, subapically expanded slightly in dorsal and ventral views, with a membranous, dorsally splitted sheath, covered with tiny spines, and followed by a serrated collar; ventral end rounded, sharply pointed dorsally; dorsal cleft at very proximal end; aedeagal apodeme as long as aedeagus, rod-shaped; ventral rod widely fused to aedeagal apodeme as in Figs. 21-23.

\section{Drosophila polymorpha Dobzhansky \& Pavan, 1943}

(Figs. 25-32)

Drosophila (Drosophila) polymorpha Dobzhansky \& Pavan, 1943:19; Streisinger, 1946:110 (male terminalia); Cunha, 1949:240 (abdominal patterns); Stalker, 1953:344 (key), 347 (male and female proboscis and palpi, and male fore-femur) 349 (epandrium, male and female palpi); Cova-Gracia \& Suárez, 1962:335(egg, puparium, male and female terminalia); Heed, 1962:176 (tip of aedeagus, referred to as apodeme); Suyo et al., 1981 (epandrium, aedeagus); Val, 1982:326 (male terminalia, paratype)

Specimen dissected. Male holotype, labelled "Bertioga, São Paulo, 4-1943 / Drosophila polimorpha (sic) TYPE/HOLOTIPO”, deposited in MZSP (São Paulo).

Male terminalia. Epandrium with about 2 setae just above surstylus, without upper setae, slightly microtrichose at dorsal area; ventral lobe absent. Cerci not fused to epandrium; tip of cercus bearing ca. 3 tightly joined setae, thinner and shorter than in D. cardini. Surstylus dorsally sclerotized, not microtrichose, with about 8 short, cone-shaped prensisetae, 18 longer, cone-shaped, sharply pointed outer setae conspicuously arranged in an ellipsoidal row (easily recognized in live specimens with an stereomicroscope), and ca.12 thin inner setae that come up to outer surface; anterior margin mostly fused to posterior margin of epandrium by membranous tissue. Decasternum as in Fig. 26. Hypandrium longer than epandrium; bow present, sclerotized; gonopod fused to paraphysis, bearing one long seta; posterior margin of gonopod (just behind the seta) projected posteriorly, then becoming membranous (partially omitted intentionally in Fig. 27); paraphysis bearing one setula. Aedeagus straight, laterally flattened, subapically expanded slightly in dorsal and ventral views, with a membranous dorsally splitted sheath, covered with tiny spines, and followed by a serrated collar; ventral end rounded, dorsally pointed; dorsal cleft at very proximal end; aedeagal apodeme as long as aedeagus, rod-shaped; ventral rod widely fused to aedeagal apodeme as in Figs. 30-31.

Although the analysis of the male terminalia seems to be the safest way to tell the species apart, some other minor external features, such as the shape of the palpi and the size and number of setae on their ventrodistal end, are valuable in sorting them. These features were included in the key presented below, which was designed to distinguish the abovementioned four species. The geographical distributions cited in the couplets were based on several papers (STREISINGER 1946; 

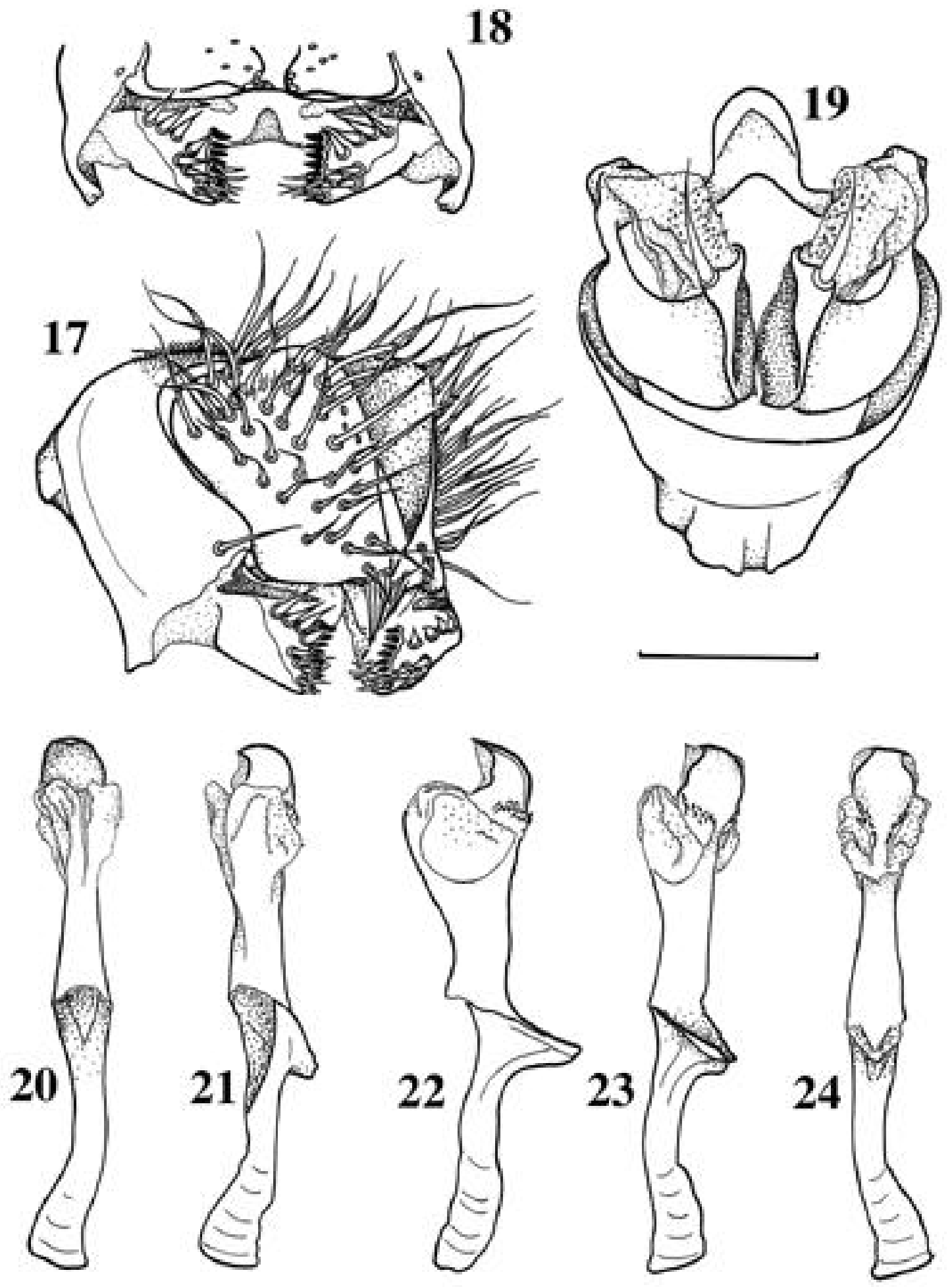

Figs. 17-24. Drosophila neocardini Streisinger, 1946, male terminalia, holotype. 17, epandrium, cerci, surstyli, and decasternum, oblique posterior view; 18, surstyli and decasternum, posterior view; 19, hypandrium and gonopods + paraphyses, posterior view; 20-24, aedeagus and aedeagal apodeme, several views from dorsal through ventral. All figures were drawn to the same scale. $\mathrm{Bar}=0.1 \mathrm{~mm}$. 

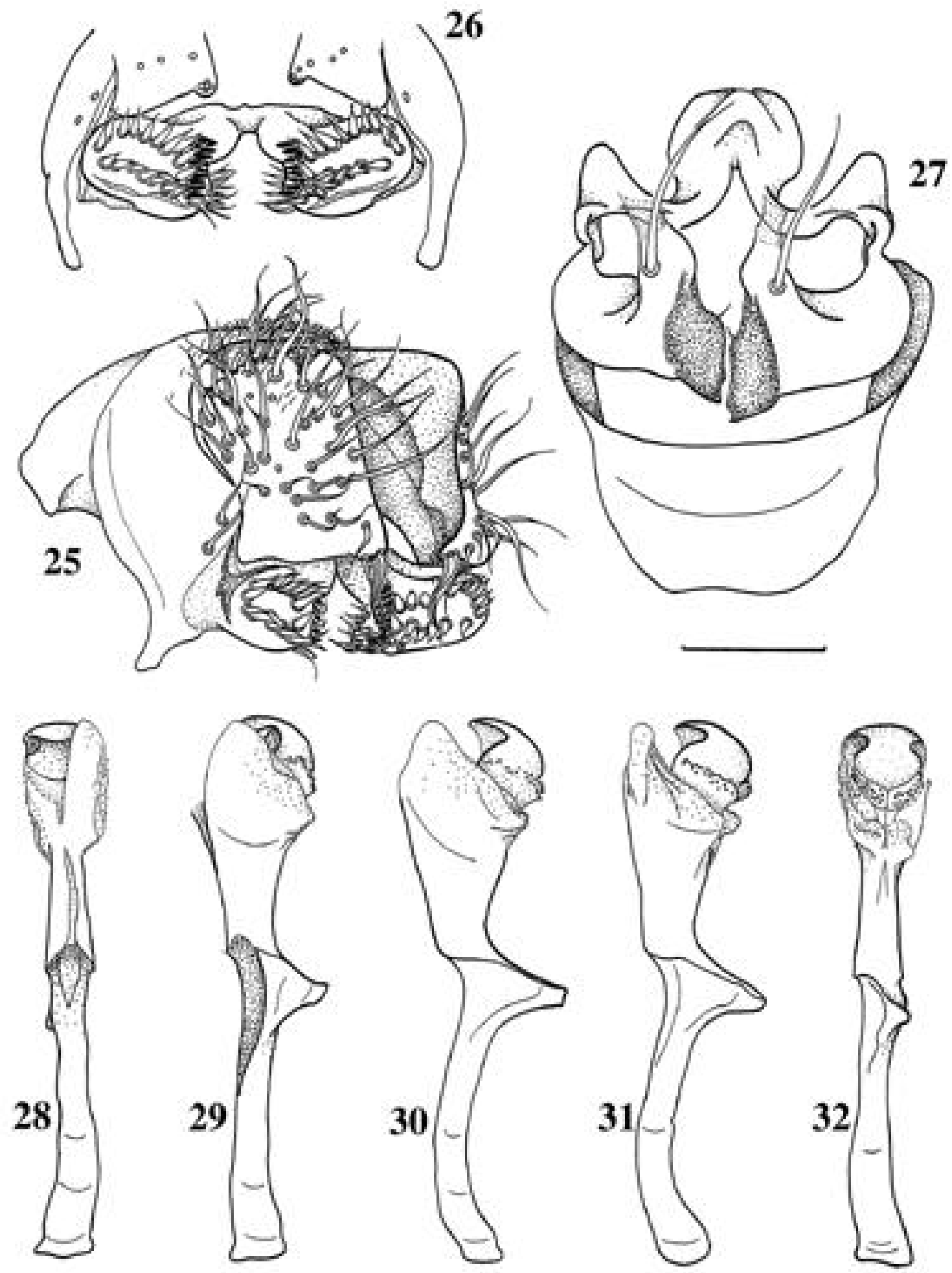

Figs. 25-32. Drosophila polymorpha Dobzhansky \& Pavan, 1943, male terminalia, holotype. 25, epandrium, cerci, surstyli, and decasternum, oblique posterior view; 26, surstyli and decasternum, posterior view; 27, hypandrium and gonopods (membranous projections intentionally omitted) + paraphyses, posterior view; 28-32, aedeagus and aedeagal apodeme, several views from dorsal through ventral (right lobe of sheath intentionally omitted). All figures were drawn to the same scale. Bar $=0.1 \mathrm{~mm}$. 
Stalker 1953; Cova-Garcia \& SuÁrez 1962; Heed \& Russell 1971; Pilares \& VÁsquez 1977; Sene et al. 1980; CARSON et al. 1983; Herforth et al. 1984; KANESHIRO 1986; BRNCiC 1987; HoenigsBerg 1995; GoÑI et al. 1998; Rafael \& Vela 2000). Additionally, the data on the occurrence of the species belonging to the cardini group in Argentina were based on the reanalysis of 36 specimens recorded by VILELA et al. (1980) and deposited in the MZSP, which were previously identified at the group level only. They are as follows: 18 specimens belonging to Drosophila cardini ( 7 from Resistencia, 6 from Puerto Tirol, 1 from Tapia, 3 from San Miguel de Tucumán and 1 from La Viña), 5 belonging to $D$. cardinoides (3 from Resistencia, and 2 from Puerto Tirol) and 13 belonging to $D$. polymorpha (8 from Resistencia, and 5 from Puerto Tirol).

\section{Key to the Brazilian species of Drosophila belonging to the cardini group}

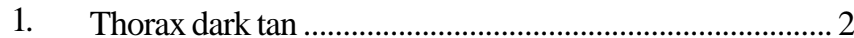

Thorax yellow or light tan 3

2(1). Palpi of both sexes conspicuously distally broad, roughly elephant's foot-shaped in males, bearing some longer setae of about same length, and ventrodistally covered with a dense brush of shorter setae (ca. half length of the longer ones), better recognized in males. Mexico, Central America, Colombia, Venezuela, Trinidad, Ecuador (Galápagos islands), Peru, Chile, Argentina, Brazil (Amazonas, Pará, Mato Grosso do Sul, Distrito Federal, Minas Gerais, Bahia, Espírito Santo, Rio de Janeiro, São Paulo, Paraná, Santa Catarina, Rio Grande do Sul) . D. cardinoides

Palpi roughly club-shaped, bearing differentiated longer setae, as in most species of its genus. Tip of cercus conspicuously bearing ca. 3 long, tightly joined setae. West Indies (Cuba, Grand Cayman, Jamaica, Haiti, Puerto Rico), USA (Hawaii, Florida), Mexico, Central America, Colombia, Venezuela, Guyana, Trinidad, Ecuador, Peru, Chile, Bolivia, Argentina, Brazil (Rio Grande do Norte, Paraíba, Bahia, Rio de Janeiro, Minas Gerais, Distrito Federal, Mato Grosso do Sul, São Paulo, Paraná, Santa Catarina, Rio Grande do Sul) D. cardini

3(1). Striking abdominal polymorphism with three types (dark, intermediate and light) of banding patterns. Surstylus with a conspicuous ellipsoidal row of cone-shaped setae (resembling goggles) in the middle area, clearly seen under the stereomicroscope (Figs. 25,26). Central America, Venezuela, Ecuador, Peru, Argentina, Uruguay, Brazil (Rio Grande do Norte, Paraíba, Bahia, Rio de Janeiro, Minas Gerais, Distrito Federal, Mato Grosso do Sul, São Paulo, Paraná, Santa Catarina, Rio Grando do Sul) D. polymorpha

Abdominal banding pattern less variable; dark band of fourth abdominal tergite usually clearly broke into four, and somewhat square-shaped, spots. Surstylus with few cone-shaped setae in the middle area not organized as above (Figs. 17,18). Colombia, Ecuador, Peru, Brazil (Mato Grosso do Sul, Bahia, Minas Gerais, São Paulo, Paraná, Santa Catarina, Rio Grande do Sul)

D. neocardini

Acknowledgements. We are grateful to FAPESP (04- Biológicas 79/ 0058) for granting a fellowship to AFGS, to Dr. D.A. Grimaldi (AMNH) and Dr. F.C. do Val (MZSP) for making the holotypes available.

\section{REFERENCES}

BRncic, D. 1987. A review of the genus Drosophila Fallen (Diptera: Drosophilidae) in Chile with the description of Drosophila atacamensis sp. nov. Revista Chilena de Entomologia 15: 37 60.

Carson, H. L.; F. C. do Val \& M. R. Wheeler. 1983. Drosophilidae of the Galápagos islands, with descriptions of two new species. International Journal of Entomology 25(4): 239-248.

Cova-Garcia, P. \& O. M. Sú́rez. 1962. Especies del genero Drosophila encontradas hasta ahora en Venezuela. Revista venezolana de sanidad y asistencia social 27(2): 317-351.

CunHA, A. B. DA. 1949. Genetic analysis of the polymorphism of color pattern in Drosophila polymorpha. Evolution 3: 239-251.

Cunha, A. B. da. 1955. Sobre duas raças de Drosophila neocardini Streisinger. Revista Brasileira de Biologia 15: 117-125.

Dobzhansky, Th. \& C. Pavan. 1943. Studies on Brazilian species of Drosophila. Boletins da Faculdade de Filosofia, Ciências e Letras da Universidade de São Paulo 36 (Biologia Geral 4): 772 .

Dobzhansky, TH. \& C. Pavan. 1950. Local and seasonal variation in relative frequencies of species of Drosophila in Brazil. Journal of Animal Ecology 19: 1-14.

Freire-Maia, N. \& C. Pavan. 1949. Introdução ao estudo da Drosophila. Cultus 1: 5-71.

Frota-Pessoa, O. 1952. Flower-feeding Drosophilidae. Drosophila Information Service 26: 101-102.

Frota-Pessoa, O. 1954. Revision of the tripunctata group of Drosophila with description of fifteen new species (Drosophilidae, Diptera). Arquivos do Museu Paranaense 10: 253-330.

Futch, D. G. 1962. Hybridization tests within the cardini species group of the genus Drosophila. University of Texas Publications 6205: 539-554.

Grimaldi, D. A. 1990. A Phylogenetic, revised classification of genera in the Drosophilidae (Diptera). Bulletin of the American Museum of Natural History 197: 1-139.

Goñi, B.; M. E. Martinez; V. L. S. Valente \& C. R. Vilela. 1998. Preliminary data on the Drosophila species (Diptera, Drosophilidae) from Uruguay. Revista Brasileira de Entomologia 42(3/4): 131-140.

HeED, W. B. 1957. A preliminary note of the cardini group of Drosophila in the Lesser Antilles. University of Texas Publications 5721: 123-124.

Heed, W. B. 1962. Genetic characteristics of island populations. University of Texas Publications 6205: 173-206.

HeEd, W. B. \& N. B. Krishnamurthy. 1959. Genetic studies on the cardini group of Drosophila in the West Indies. University of Texas Publications 5914: 155-179.

HeED, W. B. \& J. S. Russell. 1971. Phylogeny and population structure in island and continental species of the cardini group of Drosophila studied by inversion analysis. University of Texas Publications 7103: 91-130.

Herforth, R. S.; H. L. Carson \& L. Chang. 1984. A new arrival to the Hawaiian islands: Drosophila cardini. Drosophila Information Service 60: 124 . 
Hoenigsberg, H. F. 1995. Collecting Drosophila species in natural surroundings. Drosophila Information Service7: 86-87.

Hsu, T. C. 1949. The external genital apparatus of male Drosophilidae in relation to Systematics. University of Texas Publications 4920: $80-142$.

Kaneshiro, K. 1986. Drosophila cardini Sturtevant. Proceedings of the Hawaiian Entomological Society 26: 3 .

Malogolowkin, C. 1953. Sôbre a genitália dos drosofilídeos. IV. A genitália masculina no subgênero "Drosophila" (Diptera, Drosophilidae). Revista Brasileira de Biologia 13(3): 245-264.

Mourão, C. A.; A. J. Gallo \& H. E. M. C. Bicudo. 1965. Sobre a sistemática de Drosophila no Brasil, com descrição de Drosophila mendeli sp.n. e relação de espécies brasileiras do gênero Drosophila. Ciência e Cultura 17(4): 577-586.

NAPP, M. \& A. R. CoRDEIRo. 1978. Genetic variability and disequilibrium in the major esterase locus in four species of the cardini group of Drosophila. Revista Brasileira de Genética 1(3): 193-202.

Pattterson, J. T. \& W. S. Stone. 1952. Evolution in the Genus Drosophila. New York, Macmillan, $610 \mathrm{p}$.

Pavan, C. 1959. Relações entre populações naturais de Drosophila e o meio ambiente. Boletins da Faculdade de Filosofia, Ciências e Letras da Universidade de São Paulo 221 (Biologia Geral 11): 7-81.

Pilares, L. V. \& J. A. Vásquez. 1977. Especies del genero Drosophila (Diptera) registradas para el Perú. Revista Peruana de Entomologia 20(1): 103-106.

PIPKIN, S. B. 1965. The influence of adult and larval food habits on population size of neotropical ground-infesting Drosophila. American Midland Naturalist 74: 1-27.

Pipkin, S. B.; R. L. Rodriguez \& J. Leon. 1966. Plant host specificity among flower-feeding neotropical Drosophila (Diptera, Drosophilidae). American Naturalist 100: 135-156.

Rafael, V. \& D. Vela. 2000. Drosophila distribution in Ecuador. Drosophila Information Service 83: 85-88.

Sene, F. M.; F. C. Val; C. R. Vilela \& M. A. Q. R. Pereira. 1980. Preliminary data on the geographical distribution of Drosophila species within morphoclimatic domains of Brazil. Papéis Avulsos de Zoologia 33(22): 315-326.

Stalker, H. D. 1953. Taxonomy and hybridization in the cardini group of Drosophila. Annals of the Entomological Society of America 46(3): 343-358.

StReisinger, G. 1946. The cardini species group of the genus Drosophila.
Journal of New York Entomological Society 54: 105-113.

Sturtevant, A. H. 1916. Notes on North American Drosophilidae with description of twenty-three new species. Annals of the Entomological Society of America 9: 323-343.

Sturtevant, A. H. 1942. The classification of the genus Drosophila, with description of nine new species. University of Texas Publications 4213: 5-51.

Suyo, M. P.; L.V. Pllares \& J. A. VÁsquez. 1981. Analysis de la genitalia externa del macho en tres especies de Drosophila del grupo cardini. Revista Peruana de Entomologia 24(1): 165-166.

Throckmorton, L. H. 1962. The problem of phylogeny in the genus Drosophila. University of Texas Publications 6205: 207-343.

Tidon-Sklorz, R.; C. R. Vilela; F. M. Sene \& M. A. Q. R. Pereira. 1994. The genus Drosophila (Diptera, Drosophilidae) in the Serra do Cipó, state of Minas Gerais, Brazil. Revista Brasileira de Entomologia 38(3/4): 627-637.

VAL, F. C. 1982. The male genitalia of some Neotropical Drosophila: notes and illustrations. Papéis Avulsos de Zoologia 34 (27): 309347.

Val, F. C.; C. R. Vilela \& M. D. Marques. 1981. Drosophilidae of the Neotropical Region, p.123-168. In: M. AshBuRner; H. L. CARson \& J. N. Thоmpson (eds.). The Genetics and Biology of Drosophila, v.3a. London, Academic Press.

Valente, V. L. \& A. M. ARaúJo. 1991. Ecological aspects of Drosophila species in two contrasting environments in southern Brazil (Diptera, Drosophilidae). Revista Brasileira de Entomologia 35(2): 237 253.

Vilela, C. R. \& L. Mori. 1999. The genus Drosophila (Diptera, Drosophilidae) in the Serra do Cipó: further notes. Revista Brasileira de Entomologia 43(3/4): 319-328.

Vilela, C. R.; M. A. Q. R. Pereira \& F. M. Sene. 1983. Preliminary data on the geographical distribution of Drosophila species within morphoclimatic domains of Brazil. II. The repleta group. Ciência e Cultura 35(1): 66-70.

Vilela, C. R.; F. M. Sene \& M. A. Q. R. Pereira. 1980. On the Drosophila fauna of chaco and east slopes of the Andes in Argentina. Revista Brasileira de Biologia 40(4): 837-841.

WheEleR, M. R. 1949. Taxonomic Studies on the Drosophilidae. University of Texas Publications 4920: 157-195.

WheELER, M. R. \& M. P. Kambysellis. 1966. Notes on the Drosophilidae (Diptera) of Samoa. University of Texas Publications 6615: 533565 . 